\title{
IMPROVEMENT OF FIDELITY OF MOVING OBJECTS CLASSIFICATION IN GUARD SIGNALING COMPLEXES WITH SEISMIC SENSORS
}

\author{
Bohdan Volochiy $^{1}$, Mykhailo Zmysnyi ${ }^{1}$, Leonid Ozirkovskyy ${ }^{1}$, Volodymyr Onyshchenko ${ }^{2}$, Yuriy Salnyk ${ }^{2}$ \\ ${ }^{1}$ Lviv Polytechnic National University, Department of Theoretical Radio Engineering and Radio Measurement, \\ ${ }^{2}$ Hetman Petro Sahaidachnyi National Army Academy, Scientific Centre
}

\begin{abstract}
The effectiveness of guard signaling complexes (GSC), when there is an important validity of the classification of moving objects (MO), is evaluated by the following indexes: probability of GSC task execution; probability of partial fulfillment of the task; probability of user's "deception". Accordingly, the performance indicators of the GSC, in turn, depend on the indexes of the functionality of its constituents: probability of fixation of moving object by seismic sensor, probability of correct classification of $M O$ type and probability of receiving radio signal by the system of receiving and displaying information (SRDI). The article describes a discrete-continuous stochastic model of of GSC reaction to moving object crossing control zone, in which three seismic sensors are installed. Majority principle of identifying the type of moving object was used on the receiving part of the complex. A comparative analysis of the effectiveness of guard signaling complexes using one, two and three sensors in control zone are carried out.
\end{abstract}

Keywords: seismic sensor, guard radio electronic complex, efficiency indexes

\section{POPRAWA JAKOŚCI KLASYFIKACJI OBIEKTÓW RUCHOMYCH W SYSTEMACH ALARMOWYCH Z WYKORZYSTANIEM CZUJNIKÓW SEJSMICZNYCH}

\begin{abstract}
Streszczenie. Skuteczność systemów alarmowych, w przypadkach, gdy ważna jest dokładność klasyfikacji poruszajacych się obiektów, ocenia się za pomoca następujacych wskaźników: prawdopodobieństwo wykonania zadania; prawdopodobieństwo częściowej realizacji zadania; prawdopodobieństwo "oszukiwania" użytkownika. W związku z tym, wskaźniki jakości działania systemów alarmowych zależa od wskaźników funkcjonalności ich komponentów. prawdopodobieństwa ustalenia poruszajacego się obiektu za pomoca czujnika sejsmicznego, prawdopodobieństwa poprawnej klasyfikacji rodzaju poruszającego się obiektu oraz prawdopodobieństwa odbioru sygnałów radiowych przez system odbioru i wyświetlania informacji. Artykuł przedstawia dyskretno-ciagly model stochastyczny reakcji systemu alarmowego na przekroczenie strefy kontrolnej przez poruszajacy się obiekt, w której zainstalowane sa trzy czujniki sejsmiczne. Identyfikacja poruszajacego się obiektu odbywa się na wyjściu systemu na podstawie zasady większości. Porównano skuteczności systemów alarmowych z wykorzystaniem jednego, dwóch i trzech czujników sejsmicznych w strefie kontrolnej.
\end{abstract}

Słowa kluczowe: czujnik sejsmiczny, system alarmowy, wskaźniki efektywności

\section{Introduction}

In the phase of system design of guard signaling complex (GSC) it is necessary to perform research of its effectiveness with different versions of its implementation. Corresponding research must form the requirements for using GSC constituents. A future GSC must detect moving objects (MO) by seismic sensors, perform MO classification by seismic signals and transmit messages by radio channel from autonomous systems of detection, object classification and transmitting radio signals (DOCTRS) to the system of receiving and displaying information (RDI).

Seismic sensors (SS) $[11,12]$ have widespread application in designing guard systems.

The main advantages of SS use: operational conditions specify covert SS layout in the ground; a principle of detecting moving objects by SS is passive which does not imply energy emission to the environment $[3,4]$.

The GSC effectiveness (Fig. 1) is assessed by the following factors: Probability of GSC task execution; probability of partial fulfillment of the task; probability of user's "deception". Abovementioned factors of GSC effectiveness, on their part, depend on functionality factors of its constituents: probability of fixation of moving object by seismic sensor, probability of correct classification of MO and probability of delivering message about moving object in the system of receiving and displaying information. Probability of GSC task execution implies the situation when the MO, detected (fixed) in control zone, is correctly classified. Probability of partial fulfillment of the task implies the situation when the MO is detected (fixed) in control zone, but is not classified. Probability of user's "deception" implies the situation when the MO, detected (fixed) in control zone, is classified incorrectly. In all cases the message about MO with a certain probability is delivered to the user.

The effectiveness of guard signaling complex with installing one or two SSs in control zone is examined in works [7-9].

In order to perform comparative research it is necessary to develop a model of GSC reaction to MO crossing control zone with three seismic sensors. To improve the fidelity of MO classification it is suggested to use majority principle of taking decisions $\{2$ from 3$\}[2,5]$ on the receiving part of GSC.
So, actual is the task of developing a model of GSC reaction to crossing control zone by moving object where there are three seismic sensors.

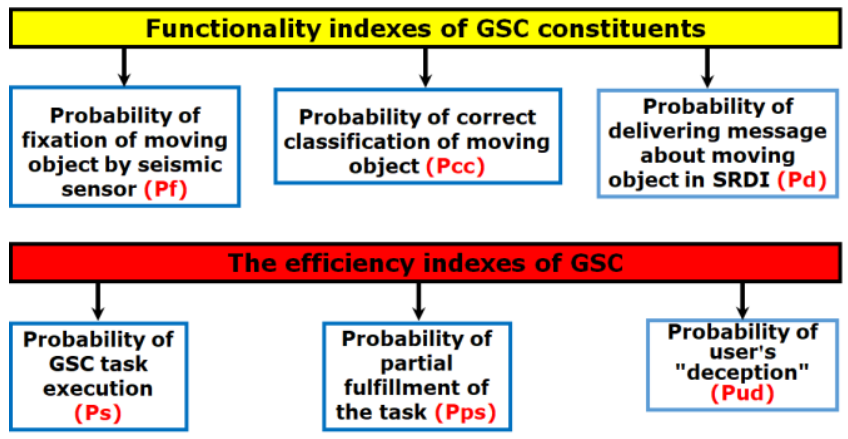

Fig. 1. Effectiveness factors of guard signaling complex and functionality factors of its constituents

The developed model allows conducting analysis of GSC effectiveness of seismic sensor sensitivity (probability of MO detecting), of effectiveness of classification method (probability of correct classification), and of effectiveness of the system of transmitting radio signals (probability of receiving radio signal). In addition, the development of the model will show the advantage of GSC using the majority principle of taking decisions. Thus, the object under study is GSC reaction to MO crossing of control zone where there are three SSs.

The task of developing a method for classification of $\mathrm{MO}$ with the use of signals from seismic sensors is complex. Therefore, it is necessary to look for such principles of constructing of GSC (technical solutions) in order to reduce the requirements to the classification method (to the value of the index functionality of the classification method). In this regard, two questions arises. How much can the value of the index of the functionality of the classification method be reduced, if:

The instead of one SS, to install two SSs in the control zone? The instead of two SSs, to install three SSs in the control zone and use the majority principle for decision-making on the type of MO according to the rule of voting " 2 of 3 " on the receiving side? 
Experimental researches have been carried out by the method of computer simulation using the software tool ASNA [12] and the formalized representation of the research object in the form of a structural automaton model [12]. ASNA software performs the following functions:

1. The development of a model in the form of a graph of states and transitions is carried out on the basis of a structural and automatic model.

2. Forms a system of Kolmogorov-Chapman differential equations on the basic of a state graph.

3. The result of solving the system of differential equations is the distribution of probabilities of staying in states.

4. Defines reliability, functionality and efficiency indexes using the necessary states.

Therefore, it is necessary to develop a structural automaton model of GSC reaction to MO crossing control zone. Structurally automatic models of the reaction of the GSC with the installation in the control zone of one and two SSs are developed and presented by the authors in articles [7,9]. This article presents the structural automatic model of the GSC reaction with the establishment in the control zone of three SDs and with the majority principle for decision-making on the type of $\mathrm{MO}$ with the rule of voting " 2 of 3 ".

\section{Principle of GSC functioning with three seismic sensors}

The GSC include three seismic sensors with autonomous systems DOCTRS, system of receiving and displaying information. The block diagram of the GSC is shown in Fig. 2. In the system of receiving and displaying information the majority principle with the election rule " 2 from 3 " is used for taking decision about correct classification of MO type. GSC reaction to crossing control zone by $\mathrm{MO}$ is presented in the following way. An object is moving across control zone.

Around the control zone there are three seismic sensors (SS1, SS2, SS3) which have to react to MO appearance in control zone. Each sensor with a defined probability can detect or not detect the moving object. That is, all three sensors, only two sensors or only one sensor could react to the moving object. It is also possible that none of the sensors could detect the moving object. It is specified by several factors, such as different distance of MO movement from the sensor, ground condition, specific character of landscape of the control zone, way of MO moving, etc. After reaction to MO, the sensor's autonomous system DOCTRS starts to perform classification of the object. Classification may be correct or incorrect. After classification procedure the autonomous system transmits a message about MO type to system of receiving and displaying information. However, the message can be delivered or not delivered. It should be noted that the majority element will be able to send a correct message about MO type only in that case if there are signals with correct classification from three or two autonomous systems DOCTRS. If there is no signal from one of SSs, and two other signals come with correct and incorrect MO classification, then in RDI there is a message "MO type is not determined".

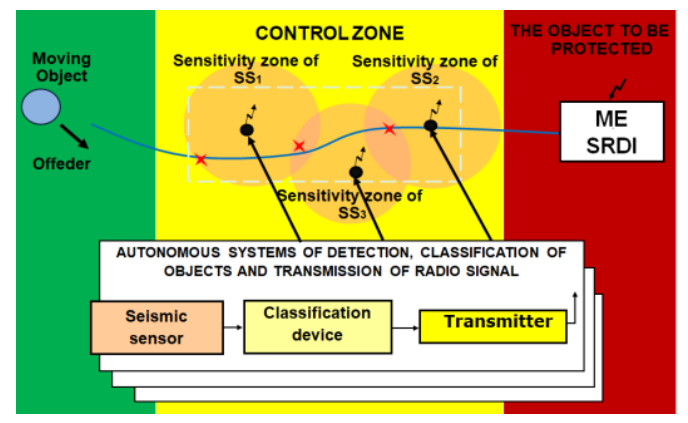

Fig. 2. Layout of three seismic sensors in control zone near the MO route and structure of autonomous system DOCTRS for each of them

\section{Development of the structural automaton mode model of GSC reaction to MO crossing control zone with majority principle of taking decision about correct classification of MO type}

The following procedures that form the GSC behavior in the process of crossing control zone by moving object are taken into account in the developed model.

Procedure 1. Detecting of moving object by seismic sensor.

A moving object may be detected or not detected, however, autonomous system DOCTRS with SSs in control zone, is in good order and ready to work. A moving object may not be detected in the following cases: it passed a seismic sensor at a safe distance; a moving object used special equipment that cannot be detected or was wearing special uniform; unsuitable place of seismic sensor location.

Procedure 2. Classification of moving object.

Alternative events are inherent in classification procedure, that is, it can be performed correctly or incorrectly. The error in classification may be caused by unsound method of processing seismic signal in autonomous system DOCTRS. Message with the result of MO classification is delivered to the system of transmitting radio signals.

Procedure 3. Delivering a message with information about MO to RDI.

The process of delivering radio signal about MO may be successful or not. Failure of message delivery to RDI may be caused by conditions of radio-wave transmission, presence of radio interference of natural and man-caused character.

Procedure 4. Taking decision about type of moving object in RDI using majority principle.

Correct decision in RDI is taken in the following situations:

1. When a signal from all three sensors came to ME, though MO was classified correctly.

2. A signal with correct classification came to ME from the first and second sensors. The third sensor either did not detect MO, or there was no message from it with correct classification, or a message was delivered with incorrect classification.

3. A signal with correct classification came to ME from the first and third sensors. The same situation is described in paragraph 2 for a signal from the second sensor.

4. A signal with correct classification came to ME from the second and third sensors. The same situation is described in paragraph 2 for a signal from the first sensor.

In order to develop structural automaton model [1] of GSC reaction to crossing control zone by moving object it is necessary to work out a reference graph of states and transitions [10]. To do this it is necessary to set values of system parameters and specify basic events which represent all processes and procedures that are included in the algorithm of its behavior. And also internal and external processes with which every GSC channel interacts during all operation period. It is also necessary to substantiate the components of state vector that will represent a state of GSC reaction.

With the help of presenting GSC procedures make a list of events taking place in the given complex. Events must be presented in pairs showing the beginning and ending of corresponding procedure. Pairs of events are shown in Table 1. Events which correspond to procedure ending are basic events for developing the model.

As far as duration of $\mathrm{MO}$ classification is less than the time of MO being in control zone, its value is taken equal to null. That is why events $1,3,5$ will be considered to be basic ones, and events 2, 4, 6 will be brought into coincidence with them respectively. On that basis we will use the following basic events in developing structural automaton model:

- Basic event 1 "Fixation of moving object by seismic sensor 1" and brought into coincidence with it basic event 2 "Ending of procedure of moving object classification by seismic sensor 1". 
- Basic event 3 "Fixation of moving object by seismic sensor 2" and brought into coincidence with it basic event 4 "Ending of procedure of moving object classification by seismic sensor $2^{\prime \prime}$.

- Basic event 5 "Detection of moving object by seismic sensor 3" and brought into coincidence with it basic event 6 "Ending of classification procedure of moving object by seismic sensor 3".

- Basic event 7 "Ending of procedure of receiving 3-rd message by majority element RDI".

Table 1. Presentation of pairs of events that fix the beginning and ending of procedures which form the GSC reaction to MO crossing control zone

\begin{tabular}{|c|c|c|c|}
\hline No. & Event-beginning & Event-ending & $\begin{array}{c}\text { Average } \\
\text { duration } \\
\text { of procedure }\end{array}$ \\
\hline 1 & $\begin{array}{l}\text { Beginning of procedure } \\
\text { of detecting moving object } \\
\text { in control zone }\end{array}$ & $\begin{array}{c}\text { Basic event } 1 \text { : detecting } \\
\text { of moving object } \\
\text { by seismic sensor } 1\end{array}$ & $1 / \lambda_{1}$ \\
\hline 2 & $\begin{array}{l}\text { Beginning of procedure } \\
\text { of MO classification } \\
\text { detected by seismic } \\
\text { sensor } 1\end{array}$ & $\begin{array}{c}\text { Basic event 2: ending } \\
\text { of procedure of } \\
\text { classification of moving } \\
\text { object detected by seismic } \\
\text { sensor } 1\end{array}$ & 0 \\
\hline 3 & $\begin{array}{l}\text { Beginning of procedure } \\
\text { of detecting moving object } \\
\text { in control zone }\end{array}$ & $\begin{array}{c}\text { Basic event } 3 \text { : detecting } \\
\text { of moving object } \\
\text { by seismic sensor } 2\end{array}$ & $1 / \lambda_{2}$ \\
\hline 4 & $\begin{array}{l}\text { Beginning of procedure } \\
\text { of MO classification, } \\
\text { detected by seismic } \\
\text { sensor } 2\end{array}$ & $\begin{array}{l}\text { Basic event } 4 \text { : ending } \\
\text { of procedure of MO } \\
\text { classification, detected } \\
\text { by seismic sensor } 2\end{array}$ & 0 \\
\hline 5 & $\begin{array}{l}\text { Beginning of procedure } \\
\text { of detecting moving object } \\
\text { in control zone }\end{array}$ & $\begin{array}{c}\text { Basic event } 5 \text { : detecting } \\
\text { of moving object } \\
\text { by seismic sensor } 3\end{array}$ & $1 / \lambda_{3}$ \\
\hline 6 & $\begin{array}{l}\text { Beginning of procedure } \\
\text { of MO classification } \\
\text { detected by seismic } \\
\text { sensor } 3\end{array}$ & $\begin{array}{l}\text { Basic event } 6 \text { : ending } \\
\text { of procedure of MO } \\
\text { classification, detected } \\
\text { by seismic sensor } 3\end{array}$ & 0 \\
\hline 7 & $\begin{array}{l}\text { Beginning of obtainment } \\
\text { of three messages to the } \\
\text { input of the majoritarian } \\
\text { element of the system RDI }\end{array}$ & $\begin{array}{l}\text { Basic event 7: ending } \\
\text { of obtainment of three } \\
\text { messages to the input } \\
\text { of the majoritarian } \\
\text { element of the system RDI }\end{array}$ & $1 / \lambda_{1-3}$ \\
\hline
\end{tabular}

In the model of GSC reaction to MO crossing control zone with majority principle of taking decisions about correct classification of MO type the following parameters are presented: $\mathrm{P}_{\mathrm{f}}$ - probability of fixation of moving object by seismic sensor, $\mathrm{P}_{\mathrm{cc}}$ - probability of correct classification of moving object, $\mathrm{P}_{\mathrm{d}}-$ probability of delivering the message about moving object, $\lambda_{1}$ - intensity of event "Detecting of MO by seismic sensor 1", $\lambda_{2}$ - intensity of event "Detecting of MO by seismic sensor 2", $\lambda_{3}$ - intensity of event "Detecting of MO by seismic sensor 3", $\lambda_{1-3}$ - intensity of event "Operation of majority element".

Let's present state vector of the system under study with the following components: V1 - shows the state of the first seismic sensor SS1 with classification result; takes values $\mathrm{V} 1=\{0 ; 1 ; 2 ; 3\}$, where 0 - initial state, 1 - sensor fixed MO and classification device identified MO type correctly, 2 - sensor fixed MO, but MO classification was incorrect, 3 - sensor did not fix moving object. V2 - shows the state of the second seismic sensor SS2 with classification result; takes value $\mathrm{V} 2=\{0 ; 1 ; 2 ; 3\}$, where 0 - initial state, 1 - sensor fixed MO, and device identified MO type correctly, 2 - sensor fixed but classification of MO was incorrect, 3 - sensor did not fix moving object. V3 - shows state of the third seismic sensor SS3 with classification result, takes value $\mathrm{V} 3=\{0 ; 1 ; 2 ; 3\}$, where 0 - initial state, 1 - sensor fixed MO type, classification was correct, 2 - sensor fixed MO but classification was incorrect, 3 - sensor did not fix moving object. V4 - shows the result of receiving a message with information about moving object; takes value $\mathrm{V} 4=\{0 ; 1 ; 2\}$, where 0 - initial state, 1 - a message is delivered, 2 - a message is not delivered. V5 - shows a state of carrying out a task and takes value V5 $=\{0 ; 1 ; 2\}$, where 0 - initial state, $1-$ a task is carried out, $2-$ a task is nor carried out.

Model of GSC reaction to crossing control zone with three SSs and with majority principle of taking decision about MO type is presented in the form of graph of states and transitions shown in article [12].

Formalized representation of a research object in the form of a structural automaton model, using the software ASNA shown in the Fig. 3-5.

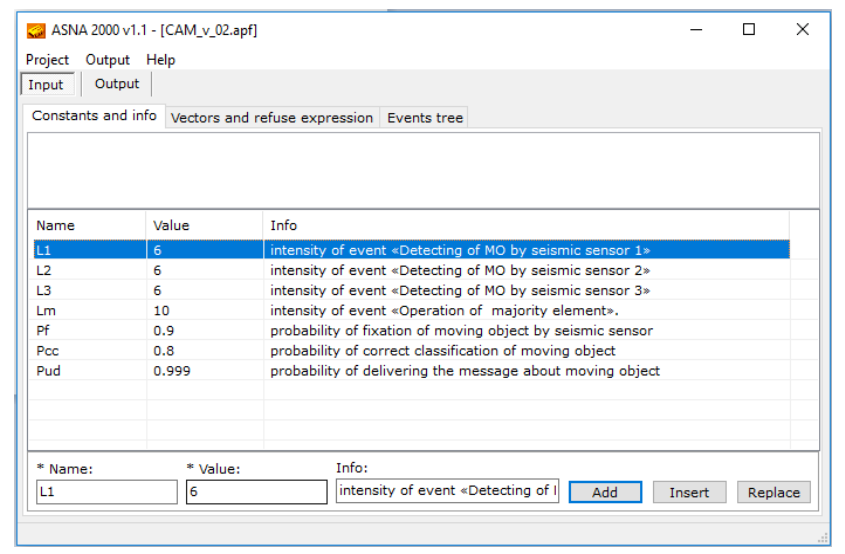

Fig. 3. Constants and info

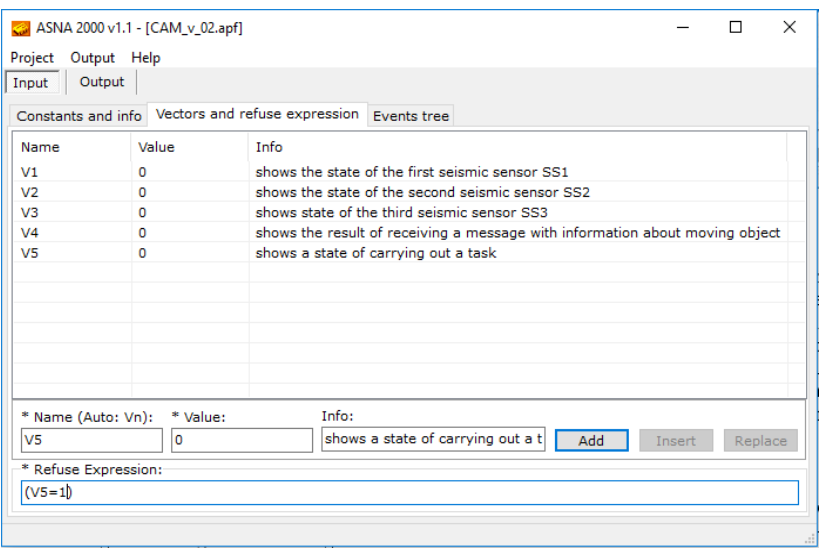

Fig. 4. Vectors and refuse expression

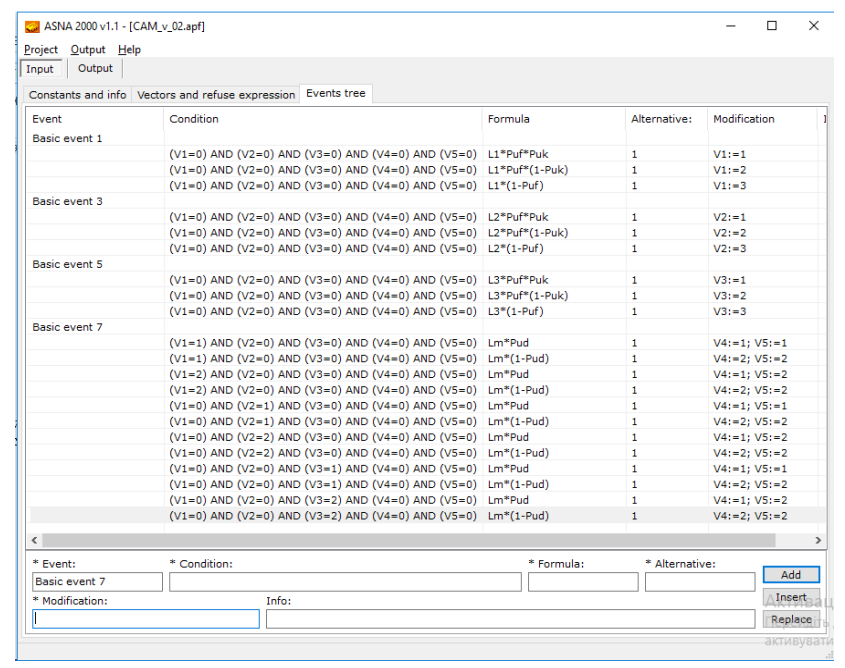

Fig. 5. Events tree

\section{Comparative research of GSC effectiveness with three versions of seismic sensors layout in control zone}

Comparative research was carried out with the following effectiveness factors of GSC constituents:

- Probability of fixation of moving object by seismic sensor $P_{\mathrm{f}}=0.8$.

- Probability of correct classification of $\mathrm{MO}-\mathrm{P}_{\mathrm{cc}}=0.8$.

- Probability of delivering message about MO in RDI $\mathrm{Pd}=0.999$. Research results are shown in Fig. 6 . 


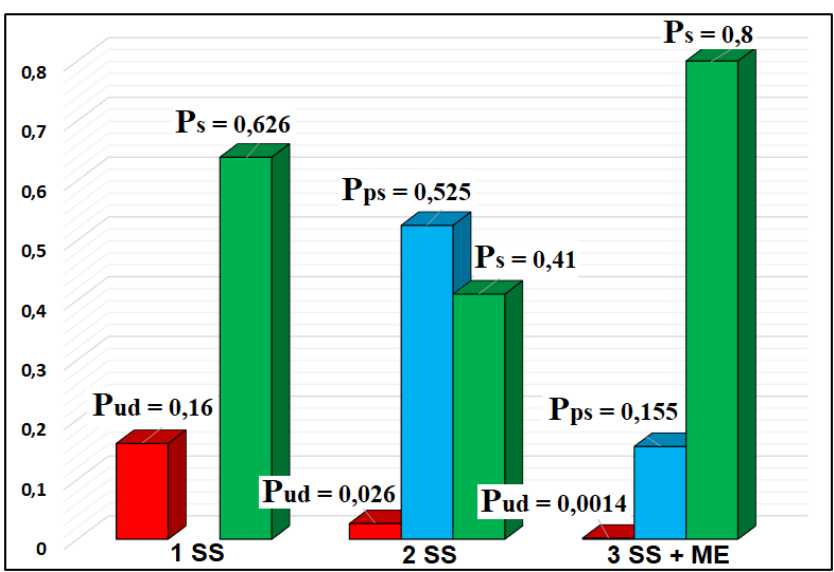

Fig. 6. Comparing of GSC effectiveness factors with the use of one, two or three seismic sensors in control zone

The results of the research confirmed the effectiveness of using GSC with three seismic sensors in control zone with the majority principle of taking decisions about MO type. The use of GSC with three SSs in control zone and with the majority principle of taking decisions about MO type in comparison with GSC with one or two SSs lessens the probability value of the user "deception" (Pud) by two orders (GSC with $1 \mathrm{SS}$ ) and by one order for GSC with two SSs.

The use of GSC with three SSs in control zone and majority principle of taking decision about MO type in comparison with GSC with two SSs and taking decision about MO type by signals coincidence lessens probability of partial fulfillment of the task 3 fold.

\section{Conclusion}

Unlike GSC with one or two seismic sensors in control zone, GSC with three seismic sensors in control zone and use of majority principle of taking decisions in the system of receiving and displaying information, provides better fidelity in identifying a type of moving object. In this case it is not necessary to raise requirements to effectiveness in the method of classifying moving objects.

\section{References}

[1] Fedasiuk D. V., Volochiy S. B.: Method of development of structural automaton models of discrete continuous stochastic systems. Radioelectronic and computer systems 6(80)/2016, 24-34.

[2] Koren Israel, Krishna C. Mani: Fault tolerant systems. Morgan Kaufmann Publishers is an imprint of Elsevier, 2007.

[3] Pricon. Technical Information - Resource access mode http://www.signalsecurity.gr/html/pdf/brochures/psicon_brochure.pdf [1.10.2018].

[4] Quantum multichannel seismic-acoustic system - Resource access mode: http://qtsi.com/wpcontent/ [1.10.2018].

[5] Shooman M. L.: Reliability of Computer Systems and Networks: Fault Tolerance, Analysis, and Design. John Wiley \& Sons, Inc., New York, 2002.

[6] Volochiy B. Y.: Assessment of potential capabilities of guard signaling complex using seismic sensors. IEEE 9th International Conference on Dependable Systems, Services and Technologies (DESSERT) 2018, 435-441.

[7] Volochiy B. Y.: Modelling of reaction of guard signalling complex to moving object appearance by seismic sensors placed in far and close control zones. Military technical collection. Army Academy 1(10)/2014, 7-13.

[8] Volochiy B. Y.: Modelling the reaction of guard signaling complex on appearance of moving object when seismosensors are deployed in far and close control zones. Modern problems of radio engineering, telecommunications and computer science: proceedings of the International Conference TCSET'2014, Publishing National University "Lviv Politechnic", Lviv 2014, 252-254.

[9] Volochiy B. Y.: Research of the dependence of the guard signaling complex on the location of seismic sensors. Eastern-European Journal of Eenterprise Technologies 2/9(68)/2014, 54-60.
[10] Volochiy B. Y.: Technology of modelling algorithms of information systems behavior. NU "Lviv Politechnika", Lviv 2004.

[11] Zvezhynskii S. S.: Perimeter concealed seismic detection means. Special equipment 2/2004, 20-28.

[12] Zvezhynskii S. S.: Problem of choosing perimeter detection means. BDI $4(44) / 2002,36-41$

Prof. Bohdan Volochiy
e-mail: bvolochiy@ukr.net

Professor of Theoretical Radio Engineering and Radio Measuring Department of Lviv Polytechnic National University Experience of teaching in higher education for is over 40 years. Author of 280 publications, including 4 monographs, 3 textbooks, 5 inventions. He has prepared 4 Doctors of philosophy (Ph.D.). Research interests are: theory and practice of system design of radioelectronic information systems.

ORCID ID: 0000-0001-5230-9921

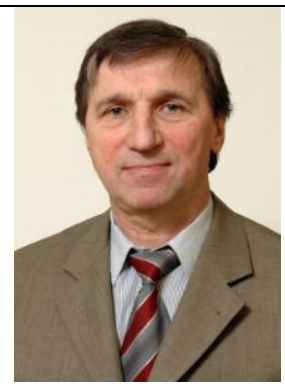

\section{Ph.D. Mykhailo Zmysnyi}

e-mail: zmysnyim@gmail.com

Senior Lecturer of Theoretical Radio Engineering and Radio Measuring Department of Lviv Polytechnic National University He has been teaching in higher educational establishments for over 5 years. The author of over 30 scientific publications. Research interests include the development of methods and tools for modeling functional and reliability behavior of fault-tolerant systems with majority structure.

ORCID ID: 0000-0002-3384-6139

\section{Ph.D. Leonid Ozirkovskyy}

e-mail: l.ozirkovsky@ gmail.com

Associate Professor of Theoretical Radio Engineering and Radio Measuring Department of Lviv Polytechnic National University.He has been teaching in higher educational establishments for over 18 years. The author of 93 scientific publications and 32 scientific and methodical works, including 2 monograph, 5 textbooks. He has prepared 3 Doctors of philosophy (Ph.D.). Research interests include the development of methods and tools for modeling functional and reliability behavior of information systems

ORCID ID: 0000-0003-0012-2908

\section{Volodymyr Onishchenko
e-mail: onishchenkovolodymyr@gmail.com}

Senior researcher of Scientific Centre of Hetman Petro Sahaidachnyi National Army Academy.

Area of research: development and improvement of theoretical fundamentals of the structure analysis and synthesis, characteristics and mathematical software for systems (complexes, samples) of equipment and their components.

ORCID ID: 0000-0002-9616-838X
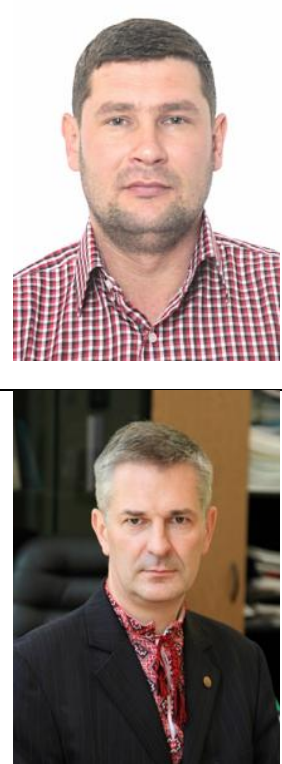

\section{Ph.D. Yuriy Salnyk}

e-mail: jurasalnik@ukr.net

Senior researcher, head of research department of Scientific Centre of Hetman Petro Sahaidachnyi National Army Academy Area of research: system engineering design and application of radio-electronic means of remote monitoring and security systems.

ORCID ID: 0000-0002-0772-6811
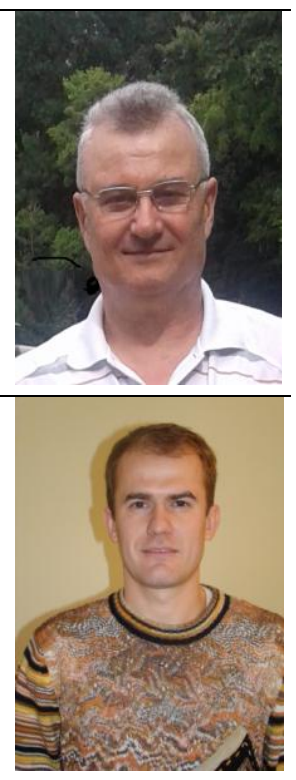

otrzymano/received: 1.10 .2018 